CLINICAL STUDY

\title{
High prevalence of thyroid peroxidase gene mutations in patients with thyroid dyshormonogenesis
}

\author{
Magdalena Avbelj, Husref Tahirovic ${ }^{1}$, Marusa Debeljak, Maria Kusekova ${ }^{2}$, Alma Toromanovic ${ }^{1}$, Ciril Krzisnik and \\ Tadej Battelino \\ University Medical Centre, University Children's Hospital, Vrazov trg 1, SI-1000 Ljubljana, Slovenia ${ }^{1}$ Department of Pediatrics, University Clinical Center \\ Tuzla, 75000 Tuzla, Bosnia and Herzegovina, and ${ }^{2} 1$ st Department of Paediatrics, University Children's Hospital, O4001 Kosice, Slovakia \\ (Correspondence should be addressed to T Battelino; Email: tadej.battelino@mf.uni-lj.si)
}

\begin{abstract}
Objective: Thyroid dyshormonogenesis is a genetically heterogeneous group of inherited disorders in the enzymatic cascade of thyroid hormone synthesis that result in congenital hypothyroidism $(\mathrm{CH})$. Thyroid peroxidase gene (TPO) mutations are one of the most common causes of thyroid dyshormonogenesis. The aim of this study was to identify TPO gene defects in a cohort of patients with thyroid dyshormonogenesis from Slovenia, Bosnia, and Slovakia.

Design and methods: Forty-three patients with permanent $\mathrm{CH}$ and orthoptic thyroid glands from 39 unrelated families participated in the study. Mutational analysis of the TPO gene and part of its promoter consisted of single-stranded conformation polymorphism analysis, sequencing, and restriction fragment length polymorphism (RFLP) analysis.

Results: TPO gene mutations were identified in $46 \%$ of participants. Seven different mutations were identified, four mutations of these being novel, namely 613C $>\mathrm{T}$ (R175X), 1519_1539del (A477_N483del), 2089G >A (G667S), and 2669G >A (G860R). Only a single allele mutation was identified in $65 \%$ of the TPO mutation carriers.

Conclusions: The results showed a higher prevalence of TPO gene mutations in thyroid dyshormonogenesis when compared with published studies. The high percentage of single allele mutations implied possible intronic or regulatory TPO gene mutations or monoallelic expression.
\end{abstract}

European Journal of Endocrinology 156 511-519

\section{Introduction}

Congenital hypothyroidism $(\mathrm{CH})$ is the most common congenital endocrine disorder, occurring in 1:30004000 newborns (1). The serious detrimental effect on the child's cognitive and motor development, which used to be a major feature of the disease, is now mostly prevented by newborn screening detection and early treatment (2).

In Slovenia, neonatal screening for $\mathrm{CH}$ was introduced in 1981 (3). The present incidence of permanent $\mathrm{CH}$ in Slovenia is approximately 1:3100 newborns, based on 58 patients identified among 181264 newborns in a 10-year period from 1994 to 2003 (data obtained from the National Registry of the Department of Endocrinology, Diabetes and Metabolism, University Children's Hospital, Ljubljana, which is the nationwide referral center for $\mathrm{CH}$ ). The neonatal thyroid-stimulating hormone (TSH) screening program in the Federation of Bosnia and Herzegovina (major part of Bosnia and Herzegovina) has been implemented since March 2005. The Federal Minister of Health accredited the implementation of the neonatal screening program for
$\mathrm{CH}$ and phenylketonuria to the Laboratory for the Detection of Congenital Metabolic Diseases at the Department of Pediatrics, University Hospital, Tuzla (4). There were 30068 newborns screened and 12 patients identified with $\mathrm{CH}$ from 1st March 2005 to 31st December 2006 (data obtained from the Federal Registry for $\mathrm{CH}$ of the Division for Endocrinology, Diabetes and Metabolism, Department of Pediatrics, University Hospital, Tuzla). The recent populationbased studies showed Slovene adolescents and Bosnian schoolchildren to be iodine sufficient $(5,6)$.

The majority of sporadic $\mathrm{CH}$ is due to developmental disorders, referred to as thyroid dysgenesis, which include the complete absence of thyroid tissue (agenesis) and a small-sized thyroid (hypoplasia) with or without associated ectopy. The less common causes of $\mathrm{CH}$ are hereditary defects in the enzymatic cascade of thyroid hormone synthesis, which share a common name, thyroid dyshormonogenesis. In this entity, the thyroid gland is found in the normal anatomical position; it is often enlarged, but with adequate levothyroxine $\left(\mathrm{LT}_{4}\right)$ substitution therapy it may also be of normal size. In a 10-year period from 1994 to 2003, 34\% of Slovene 
patients with permanent $\mathrm{CH}$ showed clinical characteristics indicative of thyroid dyshormonogenesis, which is a considerably higher proportion than reported by other groups $(2,7)$.

Thyroid peroxidase (TPO) enzyme is a thyroidspecific glycosylated hemoprotein with a short transmembrane domain that binds it to the apical membrane of the thyrocyte (2), with the catalytic part facing inside the follicle. It consists of 933 amino acids that are encoded by an mRNA of 3048 nucleotides (8). The TPO gene spans over $150 \mathrm{~kb}$ on the short arm of chromosome 2, locus 2p25, and consists of 17 exons $(9,10)$. Published molecular genetic studies suggest that TPO gene mutations are one of the most common causes of thyroid dyshormonogenesis, with several different inactivating mutations being identified in patients with total iodide organification defects (TIOD; $(7,11-28)$ ). The inheritance is autosomal recessive $(16,29)$. TPO gene mutations are also infrequently reported in patients with milder thyroid hormone insufficiency or partial iodide organification defects (PIOD; $(30,31)$ ). In the present study, the results of TPO gene mutational analysis in 43 patients with thyroid dyshormonogenesis from Slovenia, Bosnia, and Slovakia and their major clinical characteristics are presented.

\section{Subjects and methods}

\section{Patients}

Patients with permanent $\mathrm{CH}$ with morphological characteristics of dyshormonogenesis, except for those with low thyroglobulin $(\mathrm{Tg})$ levels, were invited to participate in the study. The diagnosis of $\mathrm{CH}$ was based on elevated TSH levels in heel puncture blood samples collected on filter paper between days 3 and 5 of life (cutoff limit $8 \mathrm{mU} /$; DELFIA Neonatal hTSH, PerkinElmer Life and Analytical Sciences, Wallac Oy, Finland) and confirmation by subsequent determination of TSH, $\mathrm{T}_{4}$, tri-iodothyronine, and $\mathrm{Tg}$ levels in venous blood between days 7 and 14 of life, when again for TSH the cutoff limit $8 \mathrm{mU} / \mathrm{l}$ was used. Patients started replacement therapy with $\mathrm{LT}_{4}$ within the first 2 weeks of life and continued therapy for at least 2 years. The condition was reevaluated at the age of 2 years, after 4 weeks of therapy withdrawal. Patients with repeatedly elevated TSH above the upper-normal limit $5.50 \mathrm{mU} / \mathrm{l}$ (normal values $0.35-5.50 \mathrm{mU} / \mathrm{l}$ ) were considered to have permanent $\mathrm{CH}$. At the reevaluation at the age of 2 years, thyroid size was evaluated by ultrasound and/or ${ }^{99} \mathrm{Tc}$ pertechnetate scan. Patients with in situ thyroid gland of normal size or enlarged (thyroid volume (32) more than $>0.7 \mathrm{~cm}^{3}$ or thyroid width (33) more than $>1.4 \mathrm{~cm}$ ) were considered to have dyshormonogenesis. Patients with permanent $\mathrm{CH}$ and in situ normal or enlarged thyroid gland, but with lower than normal $\mathrm{Tg}$ level (normal values 2-70 ng/ $\mathrm{ml}$ ) were not invited to participate. The perchlorate discharge test was not performed; therefore, patients with iodide organification defects were not preselected. The study protocol was approved by the local ethics committees.

A total of 43 patients from 39 apparently unrelated families consented to participate in the study. At the time of genetic analysis, the mean age of participants was 11.07 years (range 2-23 years). Written informed consent was obtained from the participants and parents in the case of minors. Thirty patients from 27 families were Slovene, 11 patients from 10 families were Bosnian, and two unrelated patients were Slovak. Six participants had neonatal total or free $\mathrm{T}_{4}$ within the normal range and serum TSH level above the cutoff but $<20 \mathrm{mU} / \mathrm{l}$. However, all of these patients required permanent replacement therapy, as confirmed at the age of 2 years.

\section{DNA isolation and amplification}

Genomic DNA was isolated from peripheral blood using the salting out procedure in all participants. Each of the 17 exons of the TPO gene, including the splicing regions, was amplified by PCR. Primers and amplification conditions are available upon request from the corresponding author. Exon 8 was amplified using two pairs of primers, due to its length. Fifty microliters of PCR mixture were composed of $1 \times$ Gold PCR buffer, $\mathrm{MgCl}_{2}$, $200 \mu \mathrm{M}$ each deoxyNTP, $0.4 \mu \mathrm{M}$ each primer, $0.4 \mathrm{U}$ AmpliTaq Gold DNA polymerase (Applied Biosystems, Foster City, CA, USA), and $200 \mathrm{ng}$ DNA. Five percent of dimethyl sulfoxide were added for amplification of exon 8 b. Thermal cycling conditions were as follows: initial denaturation at $95^{\circ} \mathrm{C}$ for $10 \mathrm{~min}$, followed by 32 cycles of denaturation at $94^{\circ} \mathrm{C}$ for $30 \mathrm{~s}$, annealing for $30 \mathrm{~s}$ and extension at $72{ }^{\circ} \mathrm{C}$ for $30 \mathrm{~s}$. Cycling was followed by a final 7-min extension at $72{ }^{\circ} \mathrm{C}$.

\section{Single-stranded conformation polymorphism (SSCP) analysis and sequencing mutational analysis}

The PCR fragments were further analyzed by SSCP analysis using the DCodeTM Universal Mutation Detection System (Bio-Rad Laboratories, Inc.). The gel matrix for SSCP contained 8,10 or $12 \%$ polyacrylamide gel (37.5:1; Bio-Rad Laboratories, Inc.) with or without $5 \%$ glycerol. Samples were electrophoresed for up to $20 \mathrm{~h}$ at a constant temperature of $5{ }^{\circ} \mathrm{C}$. The gel was stained using the GelCode Color Silver Stain Kit (Pierce, Rockford, IL, USA) according to the manufacturer's instructions. Fragments with aberrant electrophoretic mobility were subsequently sequenced using the Big Dye terminator cycle sequencing kit and ABI PRISM 310 automated sequencer (PE Applied Biosystems). Exons 3, 7 8, 9, 11 and 12 were directly sequenced in all 
Table 1 Clinical characteristics of mutation carriers and identified TPO gene mutations.

\begin{tabular}{|c|c|c|c|c|c|c|c|c|c|c|}
\hline $\begin{array}{l}\text { Family/ } \\
\text { patient }\end{array}$ & $\begin{array}{l}\text { Year of } \\
\text { birth }\end{array}$ & Origin & $\begin{array}{l}\text { TSH } \\
(\mathrm{mU} /)^{\mathrm{a}}\end{array}$ & $\begin{array}{l}\text { FreeT }_{4} \\
(\mathrm{pmol} / \mathrm{l})^{\mathrm{a}}\end{array}$ & $\begin{array}{l}\text { Total T } \\
(\mathrm{nmol} / \mathrm{l})^{\mathrm{a}}\end{array}$ & $\begin{array}{l}\mathrm{Tg} \\
(\mathrm{ng} / \mathrm{ml})^{\mathrm{a}}\end{array}$ & $\begin{array}{l}\mathrm{TSH}(\mathrm{mU} / \mathrm{I}) \text { at } \\
\text { reevaluation }\end{array}$ & $\begin{array}{l}\mathrm{Tg}(\mathrm{ng} / \mathrm{ml}) \text { at } \\
\text { reevaluation }\end{array}$ & Thyroid gland $^{\mathrm{b}}$ & TPO gene analysis results ${ }^{c}$ \\
\hline 1 & 1999 & Bosnia & $>80$ & ND & 2.6 & ND & NA & NA & Goiter & 613C $>$ T/1273_1276dupGGCC \\
\hline 2 & 2003 & Slovenia & 186 & 2.4 & ND & $>500$ & 70.63 & 7.59 & Congenital goiter $^{d}$ & 1273_1276dupGGCC/WT \\
\hline 3/a & 1983 & Slovenia & $>80$ & ND & Not detectable & ND & NA & ND & Goiter & 1273_1276dupGGCC/WT \\
\hline $3 / b$ & 1985 & Slovenia & $>120$ & ND & 16 & ND & 472 & ND & Goiter & 1273_1276dupGGCC/WT \\
\hline 4 & 1995 & Slovenia & 361 & 2.7 & ND & 209 & 40.20 & 102 & Goiter & 1273_1276dupGGCC/WT \\
\hline 5 & 2004 & Slovenia & 255.5 & 4.14 & ND & 180 & 53.59 & 75 & Normal & 1273_1276dupGGCC/WT \\
\hline 6 & 1996 & Slovenia & 13.1 & 16.2 & ND & ND & 16.7 & 10 & Normal & 1273_1276dupGGCC/WT \\
\hline 7 & 1990 & Slovakia & 64.4 & ND & 19.7 & ND & NA & NA & $\begin{array}{l}\text { Nodular goiter, follicular } \\
\text { adenoma }^{\mathrm{e}}\end{array}$ & 1273_1276dupGGCC/WT \\
\hline 8 & 1999 & Bosnia & 35.3 & ND & 0.008 & 88 & NA & NA & Goiter & 1273_1276dupGGCC/WT \\
\hline 9 & 1998 & Slovenia & 400 & 0.54 & ND & 2036 & 31.1 & 540 & Goiter & $\begin{array}{l}\text { 1273_1276dupGGCC/ } \\
\text { 1273_1276dupGGCC }\end{array}$ \\
\hline 10 & 1995 & Slovenia & 422 & 2.4 & ND & 664 & 122.60 & 530 & Goiter & $\begin{array}{l}\text { 1273_1276dupGGCC/ } \\
\text { 1273_1276dupGGCC }\end{array}$ \\
\hline 11 & 1996 & Slovenia & 603 & 13.9 & ND & ND & 78.90 & 231 & Goiter & $\begin{array}{l}\text { 1273_1276dupGGCC/ } \\
\text { 1273_1276dupGGCC }\end{array}$ \\
\hline $12 / a$ & 1986 & Bosnia & $>60$ & ND & 3.2 & 348 & NA & NA & Goiter & $\begin{array}{l}\text { 1273_1276dupGGCC/ } \\
\text { 2512delT }\end{array}$ \\
\hline $12 / b$ & 1998 & Bosnia & $>60$ & ND & 3.2 & 98 & NA & NA & Goiter & $\begin{array}{l}\text { 1273_1276dupGGCC/ } \\
\text { 2512delT }\end{array}$ \\
\hline 13 & 1991 & Slovenia & $>500$ & ND & 33 & 620 & 62.76 & 276 & Goiter & 1519_1539del/WT \\
\hline 14 & 1986 & Slovenia & 481 & ND & 10 & ND & 95.88 & ND & Goiter & 1519_1539del/WT \\
\hline 15 & 2003 & Bosnia & 306 & ND & 2.6 & ND & NA & NA & Goiter & 1519 1539del/WT \\
\hline 16 & 2003 & Bosnia & 99 & ND & 3.8 & 626 & NA & NA & Goiter & 1519_1539del/WT \\
\hline 17 & 1987 & Slovenia & 14.2 & ND & 155 & 368 & 7.40 & ND & Nodular goiter ${ }^{f}$ & $2089 \bar{G}>$ A/WT \\
\hline \multirow[t]{2}{*}{18} & 1990 & Slovenia & 433.1 & ND & 16 & ND & 24.88 & ND & Nodular goiter ${ }^{9}$ & $2485 G>A / 2669 G>A$ \\
\hline & & $\begin{array}{l}\text { Normal } \\
\text { values }\end{array}$ & $<8$ & $11.7-28.0$ & $59-163$ & $2-70$ & $0.35-5.50$ & $2-70$ & & \\
\hline
\end{tabular}

ND, not determined; NA, not available; WT, wild type.

bUltrasound was performed at the age of 2 years unless indicated otherwise.

cMutations in bold are novel.

Ultrasound was performed in neonatal period.

Ultrasound was performed at the age of 15 years.

Ultrasound was performed at the age of 18 years. 
patients, except in the three patients (nos 9, 10 and 11 in Table 1) where homozygosity for the common 1273_1276dupGGCC mutation (A397PfsX76) was discovered using NaeI RFLP analysis. In 16 patients, all exons were sequenced. Sequences were compared with the normal TPO gene sequence (GenBank access no. AH003466).

\section{Genetic analysis of the TPO promoter}

In participants, where only a single allele mutation was identified in the reading frame after the sequencing of all amplified exons, $873 \mathrm{bp}$ of the promoter region were analyzed (GenBank access no. M25701:1727-2599) to examine for the presence of regulatory mutations. The region examined included the TATA box, CpG island, and the proximal promoter TTF-1- and PAX-8-binding sites, according to previous TPO promoter descriptions $(34,35)$. Three pairs of primers were designed for promoter region analysis, as listed: TP_P1F, 5'-ttctgaagctttgcatcg-3'; TP_P1R, $5^{\prime}$-cagagatgttctgtaggaaggtca-3'; TP_P2F, 5'-tgaaagcagatcacccatga-3'; TP_P2R, 5'-cctctggccgaatgagttag- $3^{\prime}$; TP_P3F, 5'-agttggtttattctttctccetgt-3'; and TP_P3R, 5' cggctgtaactcttctgaaatg- $3^{\prime}$. Specific amplification conditions are available upon request at the corresponding author. The amplicons obtained by PCR were directly sequenced and the sequences were compared with the normal TPO promoter (GenBank access no. M25701).

\section{RFLP analysis}

Screening for the common 1273_1276dupGGCC mutation (A397PfsX76) was performed using NaeI RFLP analysis on a $2 \%$ agarose gel (11).

One hundred healthy controls (approximately $80 \%$ of Slovene ethnic origin and 20\% of Bosnian ethnic origin) and examined healthy family members were screened for the novel mutations by RFLP on a $2 \%$ agarose gel. The novel point mutation in exon 6 $(613 \mathrm{C}>\mathrm{T}(\mathrm{R} 175 \mathrm{X}))$ and a 1519_1539del mutation (A477_N483del) in exon 9 each eliminated one restriction site for endonuclease BsaXI. A silent mutation in exon $8(930 \mathrm{G}>\mathrm{A}(\mathrm{P} 280 \mathrm{P}$ or $\mathrm{p}=))$ eliminated the restriction site for endonuclease NaeI and the mutation in exon 11 (2089G>A (G667S)) eliminated the restriction site for HphI. However, a single nucleotide polymorphism placed immediately next to the mutation in exon 11 disturbed proper HphI digestions, therefore DNA samples with incomplete digestion were subsequently sequenced. A point mutation in exon 15 (2669G $>$ A (G860R)) created a novel restriction site for BclI. Restriction enzymes used are summarized in Table 2. All restriction enzymes used were purchased from New England Biolabs, Inc., Beverly, MA, USA.

\section{Specific data analysis}

For the novel mutations, phylogenetic conservation of the affected amino acid sequences among the human and mammalian TPO homologues was determined with the help of CLUSTAL program (http://www.ebi.ac.uk/ clustalw/). For the silent alteration in exon 8, 930G $>\mathrm{A}$ ( $\mathrm{P} 280 \mathrm{P}$ or $\mathrm{p} .=)$, the possible effect on exonic splicing enhancers was assessed using the ESEfinder program (http://rulai.cshl.edu/tools/ESE/).

\section{Results}

TPO gene mutations were detected in 20 out of 43 patients $(46 \%)$ with thyroid dyshormonogenesis from 18 out of 39 families (46\%). A similar prevalence was observed in Slovenians and Bosnians. Considering the incidence of 1:3100 of permanent $\mathrm{CH}$ in Slovenia, the percentage of dyshormonogenesis of $34 \%$, and the prevalence of TPO mutations of $46 \%$ from the present study, the calculated incidence of $\mathrm{CH}$ due to TPO gene mutations in the Slovene population is approximately 1:20000 newborns.

The TPO gene analysis results and patients' clinical characteristics are presented in Table 1. Mutations were numbered according to Kimura (10) and named as proposed by den Dunnen and Antonarakis (36). Two of the mutation carriers (nos 6 and 17 in Table 1) had mild hypothyroidism, while in the remainder initial laboratory values and the subsequent clinical course were indicative of a severe defect in thyroid hormone synthesis. Three patients (nos 7,17 and 18) developed nodular goiter, with patient no. 7 undergoing right lobe surgical resection at the age of 15 years. Histological examination revealed nodular hyperplasia and follicular adenoma.

Seven different mutations were identified in the reading frame of the TPO gene, four of these being novel $(613 \mathrm{C}>\mathrm{T}$ in exon 6 (R175X), 1519_1539del in exon 9 (A477_N483del), 2089G $>A$ in exon 11 (G667S), and $2669 \mathrm{G}>\mathrm{A}$ in exon 15 (G860R); Fig. 1). Of the previously known mutations, 1273_1276dupGGCC in exon 8 (A397PfsX76; (7, 11)), 2485G > A in exon 14 (E799K; (13)), and 2512delT in exon 14 (C808AfsX24; (7)) were detected. The most common mutation found in the examinees was the frequently reported inactivating mutation 1273_1276dupGGCC (A397PfsX76), which was found in patients from all three countries, in $70 \%$ of mutation carriers and in $32 \%$ of all 43 participants. The identified mutations are summarized in Table 2.

In addition, two novel silent substitutions were identified. A substitution 930G $>$ A in exon 8 (P280P or $\mathrm{p} .=$ ) was detected in a heterozygous state in a patient with no other mutations detected. A substitution $2565 \mathrm{C}>\mathrm{T}$ in exon $14(\mathrm{C} 825 \mathrm{C}$ or $\mathrm{p} .=)$ was detected in a heterozygous state in one out of the two siblings, 
Table 2 Mutations identified at the DNA and protein level, and restriction endonucleases used for RFLP.

\begin{tabular}{|c|c|c|c|c|c|}
\hline Exon & Mutation $^{\mathrm{a}}$ & $\begin{array}{l}\text { Effect on TPO } \\
\text { protein sequence }\end{array}$ & Reference & $\begin{array}{l}\text { Restriction } \\
\text { endonuclease }\end{array}$ & $\begin{array}{l}\text { Frequency of } \\
\text { mutant alleles }\end{array}$ \\
\hline 6 & $613 \mathrm{C}>\mathrm{T}$ & $\mathrm{R} 175 \mathrm{X}$ & Present study & BsaXI $^{b}$ & $1 / 86$ \\
\hline 8 & 1273_1276dupGGCC & A397PfsX76 & (11) & $\mathrm{Nael}^{\mathrm{c}}$ & $17 / 86$ \\
\hline 9 & 1519 1539del & A477 N483del & Present study & $\mathrm{BsaXI}^{\mathrm{C}}$ & $4 / 86$ \\
\hline 11 & $2089 \bar{G}>A$ & $\mathrm{G} 667 \overline{\mathrm{S}}$ & Present study & $\mathrm{Hphl}^{\mathrm{b}}$ & $1 / 86$ \\
\hline 14 & $2485 G>A$ & E799K & (14) & & $1 / 86$ \\
\hline 14 & 2512delT & C808AfsX24 & (12) & & $2 / 86$ \\
\hline 15 & $2669 G>A$ & G860R & Present study & $\mathrm{Bcll}^{\mathrm{b}}$ & $1 / 86$ \\
\hline
\end{tabular}

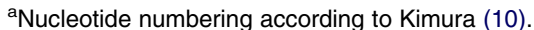

${ }^{\mathrm{b}}$ Mutation eliminates restriction site.

${ }^{\mathrm{c}}$ Mutation creates restriction site.

A

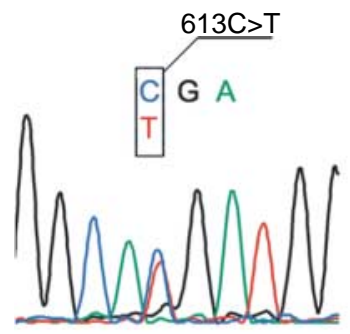

C G A

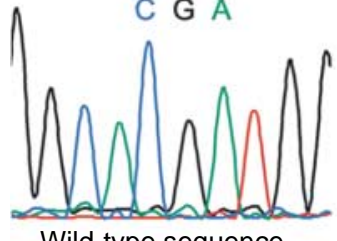

Wild-type sequence
B

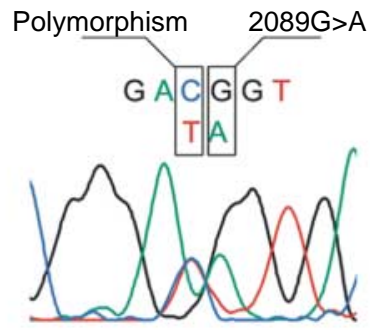

G A C GGT

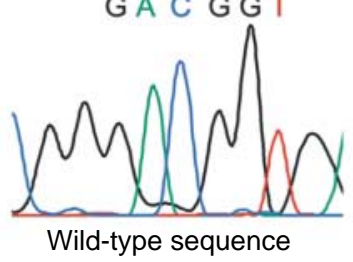

C
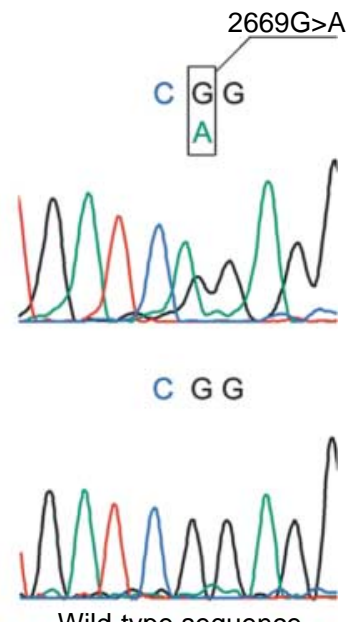

Wild-type sequence

D

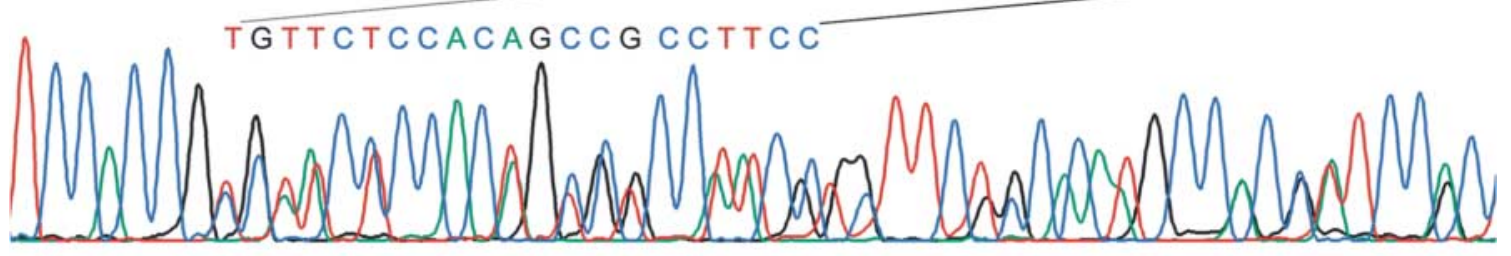

TCCACCGCCAACCCCACTGTGTCCAACGTG TTCTCCACAGCCGCCTTCCGC

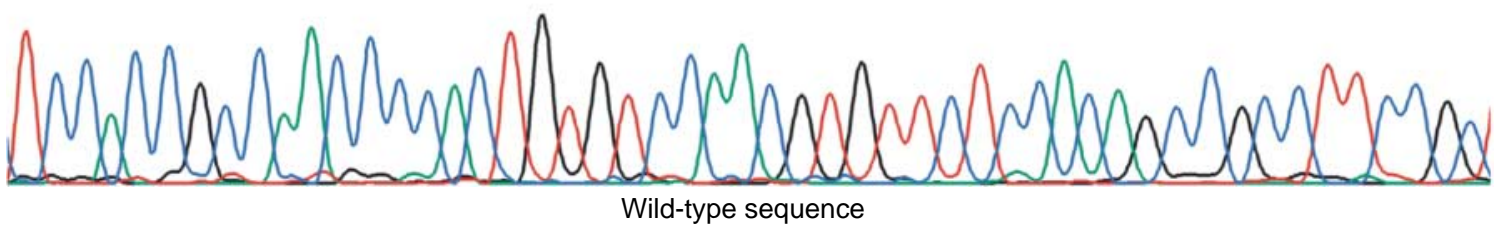

Figure 1 Novel TPO gene mutations. (A) Heterozygous $613 \mathrm{C}>$ T mutation (R175X), wild-type exon 6 sequence. (B) Heterozygous 2089G > A mutation (G667S) and heterozygous 2088C > T single nucleotide polymorphism, wild-type exon 11 sequence. (C) Heterozygous 2669G >A mutation (G860R), wild-type exon 15 sequence. (D) Heterozygous 1519_1539del mutation (A477_N483del), wild-type exon 9 sequence. 
both of whom had clinical signs of dyshormonogenesis. No mutations affecting the amino acid sequence were identified in any of the patients with silent mutations and these two patients were not included in the TPO gene mutation carriers. The 613T, 1519_1539del, 2089A, 2669A, and 930A variants were not detected in any of the 100 healthy controls, either by RFLP analysis using specific restriction enzymes or by sequencing, which was used for the 2089A detection since RFLP analysis was not accurate due to the polymorphism placed next to the mutation.

Taking into consideration all the detected mutations, except for the two silent substitutions, seven patients were found to be homozygous or compound heterozygous TPO gene mutation carriers, while in 13 patients ( $65 \%$ of mutation carriers) only a single allele mutation was identified. In these patients, including the patient with the 930G $>$ A silent substitution (P280P or p. $=$ ), all the exons analyzed by SSCP analysis were reexamined by sequencing and the TPO promoter region was investigated, except in patient no. 16 where additional DNA was not available for further analysis. In patient no. 17 a novel heterozygous promoter alteration $-540 \mathrm{~g}>$ a was identified; however, the analysis of family members showed that both this and the mutation $2089 \mathrm{G}>\mathrm{A}$ in exon 11 (G667S) were inherited from the same parent.

Five known single nucleotide polymorphisms were detected in the promoter region and in exon $1(-799 \mathrm{~g}>\mathrm{a},-706 \mathrm{~g}>\mathrm{a},-95 \mathrm{~g}>\mathrm{t},-35 \mathrm{a}>\mathrm{g}$, and $11 \mathrm{G}>\mathrm{A}$ ) and 9 known polymorphisms in the reading frame $(102 \mathrm{C}>\mathrm{G}, \mathrm{L} 4 \mathrm{~L} ; 298 \mathrm{C}>\mathrm{G}, \mathrm{P} 70 \mathrm{~A} ; 859 \mathrm{G}>\mathrm{T}$, A257S; $1207 \mathrm{G}>\mathrm{T}, \quad$ A373S; $1283 \mathrm{G}>\mathrm{C}, \quad$ S398T; 2088C $>$ T, D666D; 2235C $>$ T, P715P; 2263A $>$ C, T725P; and 2630T $>$ C, V847A). Among numerous identified intronic polymorphisms, the 96-52t $>\mathrm{g}$ single nucleotide polymorphism in intron 2 was detected in the heterozygous state in all four heterozygous carriers of a novel 1519_1539del mutation in exon 9 (A477_N483del; nos 13, 14, 15 and 16), but was not detected in any of the other study participants. In the parents of patient no. 13 the $96-52 \mathrm{t}>\mathrm{g}$ polymorphism was shown to be inherited from the same parent as the 1519_1539del mutation (A477_N483del).

\section{Discussion}

The prevalence of TPO gene mutations in the studied population $(46 \%)$ was higher than that noted in a Portuguese study, where similar inclusion criteria, without the determination of the iodide organification defect, were used and mutations identified in $24 \%$ of patients (24). While the percentage of dyshormonogenesis (34\%) in the Slovene population is higher than the $15 \%$ reported in other studies $(2,7)$, the estimated incidence of $\mathrm{CH}$ due to TPO gene mutations of 1:20000 newborns is also considerably higher when compared with the published estimate in the Dutch population, where the calculated incidence of TIOD is 1:66 000 newborns (7). The data could be compared as the TPO gene mutations mainly result in TIOD, and most of the TIOD seem to be caused by TPO gene mutations (7).

In the present study, seven different TPO gene mutations were identified, four of these being novel. Mutations were also detected in two of the six participants with milder $\mathrm{CH}$. In both patients (nos 6 and 17), only a single allele mutation was identified. In patient no. 6 the common 1273_1276dupGGCC inactivating mutation (A397PfsX76) was detected. In patient no. 17 a novel missense mutation $2089 \mathrm{G}>\mathrm{A}$ was found in exon 11 that caused an amino acid change from glycine with a nonpolar, hydrophobic residue, to serine, which is a polar and hydrophilic amino acid (G667S). Glycine in this position is highly conserved in human and mammalian TPO homologues (Table 3), Umeki et al. (23) published a functional study of the nearby mutation $\mathrm{R} 665 \mathrm{~W}$, which was detected in a patient with severe $\mathrm{CH}$. The mutation is shown to disturb plasma membrane localization in the mutated TPO protein. Considering the crystal structure of myeloperoxidase, the glycine corresponding to glycine 667 in TPO forms part of an $\alpha$-helix that interconnects two locally folded regions (37). Arginine 665 and glycine 667 form the same helical turn. Therefore, it is possible that this novel mutation reduces TPO enzyme function. However, in a recent publication, carriers of a single affected allele were not found to have any signs of thyroid dysfunction and they had normal iodide organification in vivo (29). Consequently, it is likely

Table 3 Comparison of amino acid sequences neighboring novel mutations A447_N483del and G667S in various human and mammalian peroxidases.

\begin{tabular}{|c|c|c|c|c|c|c|c|c|c|c|c|c|c|c|c|c|c|c|c|c|}
\hline Mutant TPO & $\underline{D}$ & $\underline{s}$ & $\underline{T}$ & & & & & & & & $\underline{\mathrm{V}}$ & $\underline{F}$ & $\underline{s}$ & $\underline{\mathrm{L}}$ & $\underline{R}$ & $\underline{D}$ & $\underline{S}^{667}$ & $\underline{D}$ & W & $\underline{F}$ \\
\hline Human TPO & $\bar{D}$ & $\bar{S}$ & $\mathrm{~T}$ & $\overline{A^{477}}$ & $\mathrm{~N}$ & $\mathrm{P}$ & $\mathrm{T}$ & V & S & $\overline{\mathrm{N}^{483}}$ & $\overline{\mathrm{V}}$ & $\bar{F}$ & $\bar{S}$ & $\mathrm{~L}$ & $\mathrm{R}$ & $\bar{D}$ & $\overline{G^{667}}$ & $\bar{D}$ & $\overline{\mathrm{W}}$ & $\overline{\mathrm{F}}$ \\
\hline Pig TPO & D & $\mathrm{P}$ & A & $\mathrm{V}^{476}$ & $\mathrm{D}$ & $\mathrm{P}$ & $\mathrm{T}$ & V & $\mathrm{S}$ & $\mathrm{N}^{482}$ & V & $\mathrm{F}$ & $S$ & $\mathrm{~L}$ & $\mathrm{R}$ & $\mathrm{D}$ & $\mathrm{G}^{665}$ & $\mathrm{D}$ & $\mathrm{R}$ & $\mathrm{F}$ \\
\hline Mouse TPO & $\mathrm{N}$ & $P$ & $\mathrm{~T}$ & $V^{465}$ & $\mathrm{~N}$ & $\mathrm{P}$ & $\mathrm{T}$ & V & $\mathrm{S}$ & $\mathrm{N}^{471}$ & I & $\mathrm{F}$ & $S$ & $\bar{L}$ & $\mathrm{R}$ & $\mathrm{D}$ & $G^{655}$ & D & $\mathrm{R}$ & $\mathrm{F}$ \\
\hline Rat TPO & $\mathrm{N}$ & $P$ & $\mathrm{~T}$ & $V^{465}$ & $\mathrm{~N}$ & $\mathrm{P}$ & $\mathrm{T}$ & V & $\mathrm{S}$ & $\mathrm{N}^{471}$ & V & $\mathrm{F}$ & $\mathrm{S}$ & $\mathrm{L}$ & $\mathrm{R}$ & D & $\mathrm{G}^{655}$ & D & $\mathrm{R}$ & $\mathrm{F}$ \\
\hline Human MPO & $\mathrm{N}$ & $\mathrm{D}$ & $\mathrm{S}$ & $V^{486}$ & D & $\mathrm{P}$ & $\mathrm{R}$ & I & A & $\mathrm{N}^{492}$ & V & $\mathrm{F}$ & & $\mathrm{L}$ & $\mathrm{R}$ & $\mathrm{D}$ & $G^{675}$ & $\mathrm{D}$ & $\mathrm{R}$ & $\mathrm{F}$ \\
\hline Mouse MPO & $\mathrm{N}$ & $\mathrm{D}$ & $\mathrm{S}$ & $\mathrm{V}^{460}$ & $\mathrm{D}$ & $\mathrm{P}$ & $\mathrm{R}$ & i & $f$ & $\mathrm{~N}^{466}$ & V & $\mathrm{F}$ & 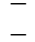 & $\bar{L}$ & $\mathrm{R}$ & $\mathrm{D}$ & $G^{649}$ & D & $\mathrm{R}$ & $\mathrm{F}$ \\
\hline Human EPO & C & $S$ & $\mathrm{~N}$ & $v^{458}$ & $\mathrm{D}$ & $P$ & $\mathrm{R}$ & V & $A$ & $N^{465}$ & $\mathrm{~V}$ & $\mathrm{~F}$ & - & A & $\mathrm{R}$ & $\mathrm{D}$ & $G^{647}$ & $\mathrm{D}$ & $\mathrm{R}$ & $\mathrm{F}$ \\
\hline Mouse EPO & C & $S$ & $\mathrm{~N}$ & $V^{459}$ & $\mathrm{D}$ & $\mathrm{P}$ & $\mathrm{R}$ & V & A & $\mathrm{N}^{465}$ & V & $\mathrm{F}$ & - & A & $\mathrm{R}$ & $\mathrm{D}$ & $\mathrm{G}^{648}$ & D & $\mathrm{R}$ & $\mathrm{F}$ \\
\hline Human LPO & S & $\mathrm{E}$ & $\mathrm{S}$ & $V^{453}$ & $\mathrm{D}$ & $\mathrm{P}$ & $\mathrm{R}$ & I & $\mathrm{S}$ & $\mathrm{N}^{459}$ & V & $\mathrm{F}$ & 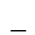 & $\mathrm{L}$ & $\mathrm{R}$ & $\mathrm{D}$ & $\mathrm{G}^{642}$ & $\mathrm{D}$ & $\mathrm{R}$ & $\mathrm{F}$ \\
\hline Mouse LPO & $\mathrm{N}$ & $\bar{E}$ & $\mathrm{~S}$ & $\mathrm{~V}^{451}$ & $\mathrm{D}$ & $P$ & $\mathrm{R}$ & I & $\mathrm{S}$ & $\mathrm{N}^{457}$ & V & $\mathrm{F}$ & - & L & $R$ & D & $\mathrm{G}^{640}$ & D & $\mathrm{R}$ & \\
\hline
\end{tabular}

TPO, thyroid peroxidase; MPO, myeloperoxidase; EPO, eosinophil peroxidase; LPO, lactoperoxidase. 
that undetected intron or regulatory mutations affected the other allele in these two patients.

The functional importance of the three novel mutations that were found in patients with severe hypothyroidism could be predicted from the putative TPO protein structure. The $613 \mathrm{C}>\mathrm{T}$ mutation creates a termination signal in exon 6 (R175X), causing a loss of the catalytic part of the enzyme.

A novel $21 \mathrm{bp}$ deletion in exon 9, 1519_1539del, causes a deletion of seven amino acids without a frame shift (A477_N483del). This short amino acid sequence is partly conserved among other mammalian peroxidases, as shown in Table 3. Several other mutations causing TIOD have been identified in close proximity by other groups - I447F, Y453D, L458P, R491H, G493S, and P499L (13, 19, 20, 22, 25). Exons 8,9 and 10 encode for the catalytic part of the enzyme and are the most frequent locations of inactivating mutations. Histidine 494 in human TPO is, according to the known myeloperoxidase structure, the proximal heme-binding histidine (37). A nearby deletion of seven amino acids would be expected to disturb proper protein folding and the final structure. The 1519_1539del mutation was detected in four apparently unrelated patients. Two of these were Bosnians, nos 15 and 16 , and the other two had Slovene citizenship, nos 13 and 14 , but their families had previously migrated to Slovenia from the southern republics of the former Yugoslavia. The nucleotide sequence of a deleted oligonucleotide and the nucleotides that directly surround it did not show the properties of loop formation as a possible mechanism for a deletion that would arise de novo on multiple occasions. However, the linkage of the deletion with an intronic substitution 96$52 \mathrm{t}>\mathrm{g}$, detected only in these four patients, implies the same ancestral origin of the mutation.

The 2669G $>$ A (G860R) is, to our knowledge, the first mutation resulting in an amino acid substitution in the TPO transmembrane region (38). It is very likely that the change from the hydrophobic glycine to the positively charged arginine disturbs the insertion of the TPO enzyme into the plasma membrane.

The functional importance of the previously known mutations was investigated by other groups. The 1273_1276dupGGCC mutation is a frame shift mutation that creates a premature termination signal in exon 9 (A397PfsX76), but is also shown to unmask a cryptic acceptor splice site in exon 9. Through the mechanism of alternative splicing normal reading frame is restored in the carboxy-terminal half of the protein (11). The $2485 \mathrm{G}>\mathrm{A}$ mutation (E799K) results in enzymatically inactive TPO, while the cellular distribution of this mutant is normal (20). The 2515delT frame shift mutation in exon 14 generates a premature termination signal in the same exon (C808AfsX24; (7)). Expression analysis showed that the mutated TPO is smaller and cannot translocate to the cell surface (39).
A novel heterozygous substitution 930G $>$ A (P280P or p. $=$ ), situated $20 \mathrm{bp}$ inside exon 8 seems to be functionally silent. It lies $20 \mathrm{bp}$ inside the exon. The computer program ESEfinder's calculations showed that this alteration eliminated two high-score exonic splicing enhancer sites, Sf2/Asf (score 4.175) and Sc35 (score 3.234). This mutation was not detected in 100 healthy controls. However, the possible effect on exon splicing could not be verified, because no thyroid tissue from this patient was available for mRNA analysis. The other novel silent substitution, $2565 \mathrm{C}>\mathrm{T}(\mathrm{C} 825 \mathrm{C}$ or $\mathrm{p} .=)$, was shown not to segregate with the disease.

In an unexpectedly high percentage of patients $(65 \%)$, only single allele mutations were identified, despite the fact that all 17 exons were analyzed in these patients, the normal SSCP analysis results were confirmed by subsequent sequencing and, in addition, $873 \mathrm{bp}$ of the proximal promoter were analyzed. In other studies, single TPO mutations were detected in only about $20 \%$ of patients with TIOD $(7,22,40,41)$. One report of mRNA analysis after thyroidectomy in a patient with TIOD and a single allele mutation proved a lack of expression of the other allele with a normal reading frame. No proximal promoter mutation was found in this patient (40).

TPO gene mutations are mostly inactivating (7). However, there are reports about TPO gene mutations that only partly diminish TPO function and result in milder clinical presentation (30). No phenotypegenotype correlation was appreciated in patients with mutations identified on both alleles. Two patients with a single allele mutation had milder clinical presentation of $\mathrm{CH}$, however, additional mutations in intronic regions or unexamined parts of regulatory regions were possible.

In conclusion, the prevalence of TPO gene mutations was considerably higher when compared with other published data. Four novel TPO gene mutations were identified in the examined population. Considering the high prevalence of single allele TPO mutations, the overall prevalence of TPO mutations with possible unidentified cryptic mutations could be even higher.

\section{Acknowledgements}

This work was supported by grants from the Ministry of Higher Education, Science and Technology and ARRS \# J3-6072 and \# J3-9663. We thank Dr Dianne Jones for reading the manuscript, Vita Dolzan, $\mathrm{MD}, \mathrm{PhD}$ for her expert advice, Katarina Trebusak Podkrajsek, PhD and Maja Zadel, BSc for their kind, expert help using the automatic sequencer, and Ms Jurka Ferran and Ms Ema Dalic for their expert technical assistance. We also thank all the patients and parents for their kind participation in our study. 


\section{References}

1 Toublanc JE. Comparison of epidemiological data on congenital hypothyroidism in Europe with those of other parts in the world. Hormone Research 199238 230-235.

2 Park SM \& Chatterjee VK. Genetics of congenital hypothyroidism. Journal of Medical Genetics 200542 379-389.

3 Krzisnik C, Battelino T, Bratanic N, Hojker S, Pavlin K, Zerjav Tansek M, Bratina Ursic N, Frelih J, Zemva B, Bratanic B, Vatovec J \& Kolar G. Results of screening for congenital hypothyroidism during the ten-year period (1981-1991) in Slovenia. Zdravniski Vestnik 199463 29-31.

4 Tahirovic H \& Toromanovic A. History, present and future of laboratory for detection of congenital metabolic diseases of the department of pediatrics in Tuzla. Pedijatrija Danas 20051 1-9.

5 Kotnik P, Sirca Campa A, Zupancic M, Stimec M, Smole K, Mis NF, Battelino T \& Krzisnik C. Goiter prevalence and urinary iodine concentration in slovenian adolescents. Thyroid 200616 769-773.

6 Tahirović H, Imširagić-Zovko S, Toromanović A \& Begić L. Assessment of the success of implementation of new rule book on salt iodination in federation of Bosnia and Herzegovina. Journal of Endocrinological Investigation 200730 9-12.

7 Bakker B, Bikker H, Vulsma T, de Randamie JS, Wiedijk BM \& De Vijlder JJ. Two decades of screening for congenital hypothyroidism in The Netherlands: TPO gene mutations in total iodide organification defects (an update). Journal of Clinical Endocrinology and Metabolism $2000 \mathbf{8 5} 3708-3712$

8 Kimura S, Kotani T, McBride OW, Umeki K, Hirai K, Nakayama T \& Ohtaki S. Human thyroid peroxidase: complete cDNA and protein sequence, chromosome mapping, and identification of two alternately spliced mRNAs. PNAS 198784 5555-5559.

9 Endo Y, Onogi S, Umeki K, Yamamoto I, Kotani T, Ohtaki S \& Fujita T. Regional localization of the gene for thyroid peroxidase to human chromosome 2p25 and mouse chromosome $12 \mathrm{C}$. Genomics 199525 760-761.

10 Kimura S, Hong YS, Kotani T, Ohtaki S \& Kikkawa F. Structure of the human thyroid peroxidase gene: comparison and relationship to the human myeloperoxidase gene. Biochemistry 198928 4481-4489.

11 Abramowicz MJ, Targovnik HM, Varela V, Cochaux P, Krawiec L, Pisarev MA, Propato FV, Juvenal G, Chester HA \& Vassart G. Identification of a mutation in the coding sequence of the human thyroid peroxidase gene causing congenital goiter. Journal of Clinical Investigation 199290 1200-1204.

12 Bikker H, den Hartog MT, Baas F, Gons MH, Vulsma T \& de Vijlder JJ. A 20-basepair duplication in the human thyroid peroxidase gene results in a total iodide organification defect and congenital hypothyroidism. Journal of Clinical Endocrinology and Metabolism 199479 248-252.

13 Bikker H, Vulsma T, Baas F \& de Vijlder JJ. Identification of five novel inactivating mutations in the human thyroid peroxidase gene by denaturing gradient gel electrophoresis. Human Mutation $199569-16$.

14 Bikker H, Waelkens JJ, Bravenboer B \& de Vijlder JJ. Congenital hypothyroidism caused by a premature termination signal in exon 10 of the human thyroid peroxidase gene. Journal of Clinical Endocrinology and Metabolism 199681 2076-2079.

15 Niu DM, Hwang B, Chu YK, Liao CJ, Wang PL \& Lin CY. High prevalence of a novel mutation (2268 insT) of the thyroid peroxidase gene in Taiwanese patients with total iodide organification defect, and evidence for a founder effect. Journal of Clinical Endocrinology and Metabolism $2002874208-4212$.

16 Pannain S, Weiss RE, Jackson CE, Dian D, Beck JC, Sheffield VC, Cox N \& Refetoff $S$. Two different mutations in the thyroid peroxidase gene of a large inbred Amish kindred: power and limits of homozygosity mapping. Journal of Clinical Endocrinology and Metabolism 199984 1061-1071.

17 Santos CL, Bikker H, Rego KG, Nascimento AC, Tambascia M, De Vijlder JJ \& Medeiros-Neto G. A novel mutation in the TPO gene in goitrous hypothyroid patients with iodide organification defect. Clinical Endocrinology 199951 165-172.
18 Tajima T, Tsubaki J \& Fujieda K. Two novel mutations in the thyroid peroxidase gene with goitrous hypothyroidism. Endocrine Journal $2005 \mathbf{5 2}$ 643-645.

19 Ambrugger P, Stoeva I, Biebermann H, Torresani T, Leitner C \& Gruters A. Novel mutations of the thyroid peroxidase gene in patients with permanent congenital hypothyroidism. European Journal of Endocrinology 2001145 19-24.

20 Bikker H, Baas F \& De Vijlder JJ. Molecular analysis of mutated thyroid peroxidase detected in patients with total iodide organification defects. Journal of Clinical Endocrinology and Metabolism 199782 649-653.

21 Kotani T, Umeki K, Yamamoto I, Maesaka H, Tachibana K \& Ohtaki S. A novel mutation in the human thyroid peroxidase gene resulting in a total iodide organification defect. Journal of Endocrinology $1999160267-273$.

22 Rivolta CM, Esperante SA, Gruneiro-Papendieck L, Chiesa A, Moya CM, Domene S, Varela V \& Targovnik HM. Five novel inactivating mutations in the thyroid peroxidase gene responsible for congenital goiter and iodide organification defect. Human Mutation 200322259.

23 Umeki K, Kotani T, Kawano J, Suganuma T, Yamamoto I, Aratake Y, Furujo M \& Ichiba Y. Two novel missense mutations in the thyroid peroxidase gene, $R 665 \mathrm{~W}$ and $G 771 R$, result in a localization defect and cause congenital hypothyroidism. European Journal of Endocrinology 2002146 491-498.

24 Rodrigues C, Jorge P, Soares JP, Santos I, Salomao R, Madeira M, Osorio RV \& Santos R. Mutation screening of the thyroid peroxidase gene in a cohort of 55 Portuguese patients with congenital hypothyroidism. European Journal of Endocrinology 2005152 193-198.

25 Wu JY, Shu SG, Yang CF, Lee CC \& Tsai FJ. Mutation analysis of thyroid peroxidase gene in Chinese patients with total iodide organification defect: identification of five novel mutations. Journal of Endocrinology 2002172 627-635.

26 Pfarr N, Borck G, Turk A, Napiontek U, Keilmann A, MullerForell W, Kopp P \& Pohlenz J. Goitrous congenital hypothyroidism and hearing impairment associated with mutations in the TPO and SLC26A4/PDS genes. Journal of Clinical Endocrinology and Metabolism 200691 2678-2681.

27 Pfarr N, Musholt TJ, Musholt PB, Brzezinska R \& Pohlenz J. Congenital primary hypothyroidism with subsequent adenomatous goiter in a Turkish patient caused by a homozygous 10-bp deletion in the thyroid peroxidase (TPO) gene. Clinical Endocrinology $2006 \mathbf{6 4} 514-518$.

28 Calaciura F, Miscio G, Coco A, Leonardi D, Cisternino C. Regalbuto C, Bozzali M, Maiorana R, Ranieri A, Carta A, Buscema M, Trischitta V, Sava L \& Tassi V. Genetics of specific phenotypes of congenital hypothyroidism: a population-based approach. Thyroid 200212 945-951.

29 Fugazzola L, Mannavola D, Vigone MC, Cirello V, Weber G, BeckPeccoz P \& Persani L. Total iodide organification defect: clinical and molecular characterization of an Italian family. Thyroid 2005 15 1085-1088.

30 Kotani T, Umeki K, Kawano J, Suganuma T, Hishinuma A, Ieiri T \& Harada S. Partial iodide organification defect caused by a novel mutation of the thyroid peroxidase gene in three siblings. Clinical Endocrinology $2003 \mathbf{5 9} 198-206$

31 Nascimento AC, Guedes DR, Santos CS, Knobel M, Rubio IG \& Medeiros-Neto G. Thyroperoxidase gene mutations in congenita goitrous hypothyroidism with total and partial iodide organification defect. Thyroid $2003 \mathbf{1 3} 1145-1151$.

32 Chanoine JP, Toppet V, Lagasse R, Spehl M \& Delange F Determination of thyroid volume by ultrasound from the neonatal period to late adolescence. European Journal of Pediatrics 1991150 395-399.

33 Yasumoto M, Inoue H, Ohashi I, Shibuya H \& Onishi T. Simple new technique for sonographic measurement of the thyroid in neonates and small children. Journal of Clinical Ultrasound 2004 $3282-85$ 
34 Abramowicz MJ, Vassart G \& Christophe D. Functional study of the human thyroid peroxidase gene promoter. European Journal of Biochemistry $1992 \mathbf{2 0 3}$ 467-473.

35 Zannini M, Francis-Lang H, Plachov D \& Di Lauro R. Pax-8, a paired domain-containing protein, binds to a sequence overlapping the recognition site of a homeodomain and activates transcription from two thyroid-specific promoters. Molecular and Cellular Biology 199212 4230-4241.

36 den Dunnen JT \& Antonarakis SE. Nomenclature for the description of human sequence variations. Human Genetics 2001 109 121-124.

37 Zeng J \& Fenna RE. X-ray crystal structure of canine myeloperoxidase at 3 A resolution. Journal of Molecular Biology 1992226 185-207.

38 Libert F, Ruel J, Ludgate M, Swillens S, Alexander N, Vassart G \& Dinsart C. Complete nucleotide sequence of the human thyroperoxidase-microsomal antigen cDNA. Nucleic Acids Research 1987 156735 .
39 Kotani T, Umeki K, Yamamoto I, Ohtaki S, Adachi M \& Tachibana K. Iodide organification defects resulting from cosegregation of mutated and null thyroid peroxidase alleles. Molecular and Cellular Endocrinology 2001 182 61-68.

40 Fugazzola L, Cerutti N, Mannavola D, Vannucchi G, Fallini C, Persani L \& Beck-Peccoz P. Monoallelic expression of mutant thyroid peroxidase allele causing total iodide organification defect. Journal of Clinical Endocrinology and Metabolism $2003 \mathbf{8 8}$ 3264-3271.

41 Medeiros-Neto G, Gil-Da-Costa MJ, Santos CL, Medina AM, Silva JC, Tsou RM \& Sobrinho-Simoes M. Metastatic thyroid carcinoma arising from congenital goiter due to mutation in the thyroperoxidase gene. Journal of Clinical Endocrinology and Metabolism $1998 \mathbf{8 3} 4162-4166$.

Received 19 January 2007

Accepted 26 February 2007 